\title{
KAJIAN PENDAHULUAN SISTEM PEMANFAATAN AIR HUJAN
}

\author{
Introduction Study Of Rain Water Use System \\ Haryoto Indriatmoko dan Nugro Rahardjo \\ Pusat Teknologi Lingkungan, BPPT
}

\begin{abstract}
Abstrak
Air hujan merupakan sumber air yang berlimpah, terutama pada musim penghujan. Sebaliknya bila air hujan tidak dikelola dengan baik akan dapat menimbulkan bencana, seperti banjir dan tanah longsor. Karena itu sangatlah penting untuk mengelola air hujan sebaik-baiknya, yaitu dengan cara menampung air hujan dan kemudian meresapkannya kembali ke dalam tanah. Banyak Negara sudah membuktikan hasil yang baik dalam memanfaatkan air hujan untuk berbagai keperluan. Republik Dominika, Singapura, Jepang, China, Thailand dan Indonesia adalah 6 negara yang telah mempunyai banyak penerapan pemanfaatan air hujan dengan sangat baik. Air hujan dapat digunakan sebagai sumber air bersih untuk memenuhi kebutuhan air minum. Upaya pembuatan sumur resapan untuk air hujan agar meresap kembali ke dalam tanah adalah suatu usaha yang sangat baik untuk memelihara dan melestarikan potensi air tanah. Disamping itu, infiltrasi air hujan ke dalam tanah juga dapat mencegah penurunan muka tanah. Karena pentingnya sistem pengelolaan air hujan, maka sebaiknya dimasukkan dalam edukasi kurikulum dari tingkat dasar hingga sekolah menengah atas. Demikian juga halnya dengan implementasi pemanfaatan air hujan yang harus didukung oleh peraturan dan regulasi yang mengikat secara nasional.
\end{abstract}

Kata Kunci : Pengelolaan air hujan, sumur resapan.

\begin{abstract}
Rainwater is an abundant source of water, especially during the rainy season. But otherwise if it is not managed properly, it can lead to disasters, such as floods or landslides. Therefore it is very important to harness rainwater by doing the best way, ie by the rain harvesting and then infiltrating the water back into the ground. Many countries have shown good results in the use of rainwater for various purposes. Dominican Republic, Singapore, Japan, China, Thailand and Indonesia are 7 countries which have a lot of implementing rainwater utilization system very well. Rainwater can be used as a source of clean water to meet the drinking water needs. Artificial recharge for rain water lets the water goes to infiltrate back into the soil is a powerful effort to maintain and preserve the ground water potential. Besides, infiltration of rainwater into the soil also can prevent land subsidence. Because of the importance of rainwater management system, it should be included in the educational curriculum both for elementary to upper secondary level. Similarly, the obligation for proper implementation must also be supported by adequate rules or regulations.
\end{abstract}

Keywords : Rainwater management, artificial recharge.

\section{PENDAHULUAN}

\subsection{Latar Belakang}

Banyak daerah yang mengalami kekurangan sumber air bersih karena kuantitas air tanahnya sedikit, kualitas air tanahnya kurang baik atau sungai yang ada debitnya sedikit. Sedangkan sistem penyediaan air minum dari PDAM belum dapat melayani seluruh penduduk yang ada. Kondisi ini makin memburuk pada musim kemarau, sehingga mengakibatkan timbulnya waterborne diseases (seperti cholera, typhus, penyakit kulit, saluran pencernaan, dll.) (Samsuhadi, 2009). Dari aspek lainnya, perubahan penggunaan lahan dari suatu kawasan yang belum terbangun menjadi kawasan terbangun akan menyebabkan berkurangnya lahan terbuka hijau. Perubahan ini telah nyata memberikan dampak terhadap berkurangnya zona penyerapan air hujan secara alami, sehingga jika 
hujan turun maka air hujan akan dengan cepat berubah menjadi air limpasan. Air hujan yang awalnya mempunyai banyak kesempatan atau peluang untuk meresap ke dalam tanah, namun akibat perubahan fungsi atau penggunaan lahan, serta pengerasan lahan, maka kesempatan air untuk meresap ke dalam tanah menjadi hilang atau jauh berkurang.

Pengurangan cadangan air tanah sebagai akibat dari pemakaian air tanah yang berlebihan tidak dapat lagi diganti oleh meresapnya air hujan ke dalam tanah. Untuk alasan ini, maka diperlukan suatu usaha meresapkan air hujan ke dalam tanah seoptimal mungkin, baik secara alami maupun artifisial (buatan). Di antara pemerintah daerah yang telah membuat peraturan pembangunan sumur resapan adalah Pemerintah Daerah Khusus Ibu Kota Jakarta, yaitu dengan dikeluarkannya SK Gubernur No. 115 Tahun 2001 tentang pembuatan sumur resapan di Propinsi Daerah Khusus Ibukota Jakarta. Keputusan ini bersifat wajib bagi penanggung-jawab bangunan. Yang dimaksud dengan penanggungjawab bangunan tersebut adalah pemilik/penyewa bangunan baik perorangan maupun badan hukum yang diberi hak atau kuasa untuk menempati atau mengelola bangunan tersebut.

Sumur resapan adalah sistem resapan buatan yang dapat menampung air hujan yang langsung dari atap atau pipa talang bangunan (Sudinda,T, 2009). Resapan dapat berbentuk sumur, kolam resapan, saluran porous dan yang sejenisnya. Proses terjadinya resapan dimulai dari bagian air hujan yang mengalir melalui saluran penghubung dan masuk tertampung dalam sumur resapan yang memungkinkan terjadinya infiltrasi ke dalam tanah. Proses meresapkan air hujan dengan mekanisme sumur resapan disebut juga dengan resapan buatan. Proses resapan secara alami terjadi pada daerahdaerah yang porous, misalnya sawah, tanah lapangan, permukaan tanah yang terbuka, hutan, halaman rumah yang tidak tertutup dan lain-lain. Air hujan yang jatuh ke permukaan tanah pada awalnya akan membasahi tanah, bangunan, tumbuhtumbuhan dan batuan. Ketika air hujan tersebut jatuh pada daerah yang berpori, maka akan meresap ke dalam tanah sebagai air infiltrasi dan air tersebut semakin lama akan meresap lebih dalam lagi sampai memasuki daerah aquifer dan akhirnya menjadi air tanah.

Berdasarkan masalah yang ada serta tuntutan keadaan untuk melestarikan lingkungan, maka dipandang perlu untuk mulai membangun sarana untuk menampung air hujan dan meresapkan limpahan air hujan ke dalam sumur resapan. Air yang tertampung dalam sarana penampung air hujan dapat dimanfaatkan untuk keperluan seharihari dan bahkan untuk air minum. Untuk mencapai kualitas sebagai sumber air minum yang tidak membahayakan kesehatan, maka diperlukan teknologi pengolahan air tepat guna yang sesuai dengan daerah tersebut.

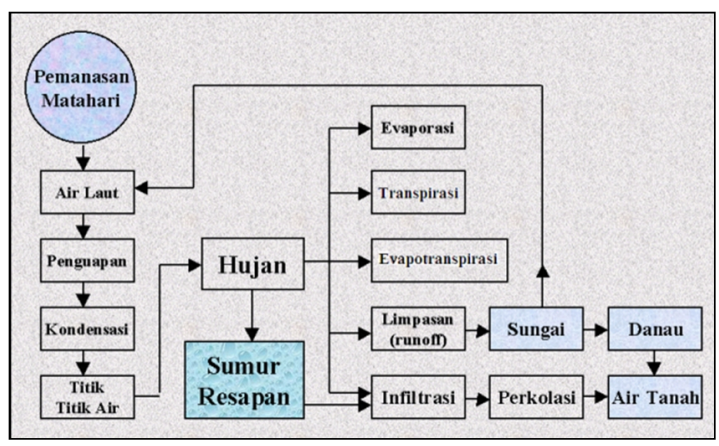

Gambar 1 : Siklus Air dan Pemanfaatan Sumur Resapan.

\subsection{Tujuan dan Sasaran Kegiatan}

Tujuan dari kegiatan ini adalah melakukan kajian awal atau pendahuluan dalam pemanfaatan air hujan guna keperluan melestarikan air tanah. Berdasarkan kajian awal sistem pemanfaatan air hujan tersebut, sasaran kegiatan ini diarahkan untuk memperoleh perbandingan di berbagai negara tentang sistem pemanfaatan air hujan. Dalam batasbatas tertentu, selanjutnya hasil ini juga untuk disosialisasikan kepada beberapa pemerintah daerah di Indonesia.

\subsection{Metodologi}

Tahapan dalam pelaksanaan kegiatan ini adalah :

- Studi Literatur

Dalam melakukan kajian pendahuluan untuk sistem pemanfaatan air hujan di berbagai negara di Asia khususnya, dibutuhkan informasi tentang situasi dan kondisi sistem pemanfaatan air hujan di 4 negara di Asia (Singapura, Jepang, China dan Thailand), maka studi literatur yang berupa informasi terkini di negara-negara tersebut haruslah dilakukan dengan seksama. Untuk negara Indonesia sendiri literatur di bidang hukum (peraturan dan keputusan kepala daerah tertentu) tentang pengelolaan atau pemanfaatan air hujan juga sangat bermanfaat untuk dijadikan dasar-dasar pertimbangan, terutama dalam pembahasan sistem pemanfaatan air hujan. Disamping itu berdasarkan literatur yang ada, beberapa permasalahan yang muncul akibat 
tidak dilakukannya sistem pemanfaatan air hujan juga akan dibahas dalam kajian ini.

\section{- Studi Banding}

Dalam kajian awal sistem pemanfaatan air hujan akan diungkapkan sejauh mana perbandingan di 4 negara di Asia, yaitu Singapura, Jepang, China dan Thailand, dalam membuktikan bahwa sistem pemanfaatan air hujan adalah cara yang baik dan harus diterapkan di masyarakat. Sementara itu di Indonesia walaupun regulasi-regulasi tentang sumur resapan sudah disosialisasikan, namun kenyataannya masih sangat lemah dalam hal monitoring dan penerapannya. Karena itu dengan melakukan studi banding, maka akan dapat lebih nyata lagi untuk dapat mengambil manfaat positifnya.

- Pembahasan

Berdasarkan studi literatur yang telah dilakukan dan melaksanakan studi banding, maka tahap berikutnya adalah pembahasan beberapa hal tentang pemanfaatan air hujan, khususnya di Indoneia, berikut dengan contoh implementasinya.

\section{PEMANFAATAN AIR HUJAN DALAM PENGELOLAAN AIR TANAH}

\subsection{Pengelolaan Sumberdaya Air Tanah}

Tujuan utama dari pemanfaatan air tanah adalah sebagai cadangan untuk memenuhi kebutuhan air bersih, jika air permukaan sudah tidak memungkinkan lagi dimanfaatkan, baik secara kuantitatif (yang biasanya dilakukan oleh perusahaan air minum), maupun secara kualitatif karena air permukaan sudah terkotori atau tercemar sehingga membahayakan untuk dikonsumsi oleh penduduk secara langsung. Oleh karena itu, alternatif pasokan air yang dilakukan dengan ekstraksi air tanah sifatnya hanya sementara dan terbatas pada air tanah dangkal.

Penggunaan air tanah harus tidak melebihi kapasitas maksimum, yaitu jumlah maksimum air tanah yang secara teknis dapat diekstraksi tanpa mengganggu keseimbangan dan stabilitas pasokan. Istilah "safe yield" atau batas aman sebagai salah satu indikator penggunaan debit air tanah secara maksimum didefinisikan pertama kali oleh Lee 1915 (lihat Domenico dan Schwartz, 1990) sebagai berikut :

"The limit to the quantity of water which can be withdrawn regularly and permanently without dangerous depletion of the storage reserve", yang kemudian dikembangkan oleh Meinzer 1923 (lihat Freeze dan Cherry, 1979) yang mendefinisikan "safe yield" sebagai :

"The rate at which water can be withdrawn from an aquifer for human use without depleting the supply to the extent that withdrawal at this rate is no longer economically feasible".

Sumberdaya air tanah yang meskipun secara geologi memperlihatkan potensi yang besar, memiliki banyak faktor keterbatasan. Akumulasi dari keterbatasan ini menghasilkan resultante berupa sumberdaya air tanah yang tidak berlanjut, artinya pemanfaatan air tanah secara jangka panjang atau permanen, akan menimbulkan masalah negatif jika tidak dikelola dengan baik.

\subsection{Penurunan Muka Tanah.}

Dalam beberapa dekade terakhir ini sudah menjadi kenyataan bahwa pemanfaatan air tanah yang tidak terkendali mengakibatkan dampak negatif pada lingkungan (Freeze dan Cherry, 1979). Di beberapa lokasi di dunia pemompaan air tanah dari sistem aquifer-aquitar yang tidak terkonsolidasi dengan baik mengakibatkan penurunan muka tanah. Poland dan Davis 1969 dan Poland 1972 (lihat Domenico dan Schwartz, 1990) memaparkan insiden penurunan muka tanah sebagai akibat pengambilan cairan dari bawah tanah. Dalam pemaparannya insiden penurunan muka tanah ada hubungannya dengan produksi minyak dan gas bumi. Terdapat tiga kasus ladang minyak Wilmington di Long Beach, California, dan mengambilan air tanah yang berlebihan di kota Meksiko, dan di lembah San Joaquin, California, Amerika Serikat yang memperlihatkan kecepatan penurunan muka tanah hampir 1 meter setiap tiga tahun dalam pengamatan selama 35 tahun, yaitu dari tahun 1935 hingga tahun 1970.

Jika pemompaan air tanah dapat menyebabkan terjadinya kerucut depresi, sebaliknya secara teoritis kegiatan penyuntikan atau pemompaan air ke dalam aquifer dapat menaikkan muka air tanah atau menaikkan tinggi tekan air tanah pada aquifer artesis. Proses ini secara analogi adalah kebalikan dari proses pemompaan air tanah keluar atau ke atas (Freeze dan Cherry, 1979). Secara fisik skema ini sudah pernah diterapkan di beberapa tempat di dunia antara lain di California, Amerika Serikat (Domenico dan Schwartz, 1990). Teknologi ini dikenal dengan sebutan "Water Factory 21". Air baku yang disuntikkan ke dalam tanah melalui sumur bor dengan dalam sesuai 
dengan letak aquifer air tanah yang menjadi tujuannya. Skema imbuhan buatan (artificial recharge) ini sudah dioperasikan sejak Oktober 1976 yang terletak di area pesisir Orange County, California, Amerika Serikat. Proyek ini terdiri atas 23 sumur injeksi yang membentang sepanjang 4 mil, dengan jumlah volume air yang diinjeksikan sebanyak 15 juta galon setiap hari untuk memasok air tanah di kawasan tersebut yang juga sekaligus membendung perambatan intrusi air laut di kawasan pesisir tersebut.

\subsection{Pengisian Air Tanah Buatan}

Peningkatan tuntutan untuk pemenuhan kebutuhan air dan ditambah dengan keprihatinan untuk perlindungan lingkungan membutuhkan berbagai kiat manajemen air yang berinovasi. Resapan buatan air tanah adalah proses penambahan air ke aquifer melalui usaha manusia. Banyak teknik dan tujuan yang berbeda untuk menciptakan resapan buatan. Berbagai program kegiatan telah dilaksanakan secara bervariasi, tetapi biasanya melibatkan air permukaan yang disimpan dalam aquifer untuk digunakan di waktu mendatang. Pemulihan dari air tanah yang disimpan umumnya adalah dengan sarana sumur resapan.

Meskipun maksud dari resapan buatan pada umumnya adalah untuk meningkatkan cadangan air tanah agar dapat digunakan dikemudian hari, kegiatan insidental seperti irigasi, pembuangan air hujan, kebocoran saluran, dan pipa air bocor juga dapat mengakibatkan resapan buatan air tanah. Mengisi ulang secara buatan dan penyimpanan aquifer serta pemulihannya adalah sistimatika manajemen yang sangat baik dan efektif untuk membantu mengimbangi tuntutan peningkatan pemanfaatan air dan sekaligus melakukan upaya konservasi potensi air tanah. Berbagai teknik, metode dan keadaan untuk proses ini sangat luas dan berkembang.

Mengisi ulang secara buatan mempunyai beberapa bentuk struktur. Salah satunya adalah teknik permukaan menyebar (surface spreading technique). Pengisian buatan dengan teknik ini melibatkan air cadangan di permukaan di daerah di mana air bisa meresap ke aquifer dangkal. Cekungan yang menebar, bendung di saluran sungai, alur, parit, dan saluran air adalah contoh resapan buatan umum (lihat Gambar 2).

Teknik injeksi menggunakan sumur untuk implementasi resapan buatan. Sumur injeksi biasanya memasukkan air langsung ke aquifer artesis di mana Surface Spreading Techniques tidak bisa dilakukan. Sumur injeksi juga membutuhkan perawatan untuk menghilangkan partikel, pertumbuhan mikroba, dan presipitat kimia (zat padat). Sumur injeksi digunakan di banyak negara. Sebagai contoh, sumur tersebut telah menjadi bagian penting dari sistem pasokan air di Israel sejak tahun 1956. Masyarakat umumnya memandang struktur resapan buatan sebagai cara yang lebih ramah lingkungan untuk mengelola air, bukan membangun bendungan untuk penyimpanan kelebihan air permukaan. Namun penggunaan resapan buatan di setiap lokasi masih harus menghadapi berbagai hambatan teknis, hukum, dan keuangan.

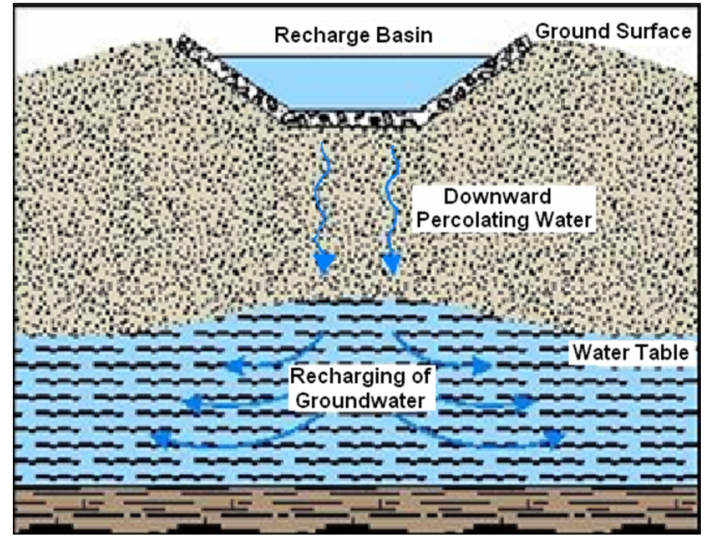

Gambar 2 : Generalisasi Penampang Resapan buatan Dari Permukaan Tanah Menggunakan Surface Spreading Techniques.

Pemilihan lokasi untuk resapan buatan sangat penting. Keberhasilan sudah dialami di beberapa jenis aquifer. Idealnya, aquifer yang akan menyimpan, dan mengirimkan air dengan jumlah yang diinginkan, air resapan yang masuk diusahakan untuk tidak mempengaruhi secara signifikan atau tidak menurunkan kualitas kimia air. Selain itu, permeabilitas aquifer dangkal seharusnya tidak membatasi infiltrasi dengan permukaan menyebar. Investigasi lokasi (situs) untuk resapan buatan harus mencakup pemetaan hidrogeologi aquifer tersebut untuk mengidentifikasi karakteristik aquifer. Teknologi lanjutan dengan menggunakan simulasi komputer untuk pemodelan aliran air tanah dan transportasi akan sangat membantu dalam menentukan besaran dan lokasi injeksi.

Ketersediaan air sering menjadi pertimbangan yang paling penting bagi waktu resapan buatan. Dalam kebanyakan kasus hal ini berpengaruh kuat terhadap cuaca musiman. Biasanya, resapan buatan dengan teknik penyebaran menggunakan air permukaan tanpa pengolahan sebagai sumbernya. Sedangkan teknik 
injeksi telah menggunakan air yang diolah, yang disesuaikan untuk kondisi spesifik lokasi. Injeksi (dengan air limbah yang biasanya diolah terlebih dahulu) merupakan pasokan yang lebih stabil dan tidak bergantung pada musim. Pada musim penghujan, kondisinya bisa sangat berbeda. Curah hujan yang sangat besar dan tidak adanya bidangbidang atau ruang terbuka hijau untuk peresapan air hujan akan dapat menyebabkan banjir. Setidaknya ada 4 upaya yang dapat dilakukan untuk menanggulangi banjir, yaitu:
a. Mengoptimalkan penampungan air.
b. Penerapan sumur resapan.
c. Penataan lahan yang tepat dan penghijauan.
d. Melakukan evaluasi drainase.

Uraian mengenai keempat upaya tersebut dapat dijelaskan pada bagian berikut.

\subsection{Penampungan Air Hujan}

Penerapan suatu teknologi Pemanfaatan Air Hujan (PAH) yang tepat memungkinkan pemanfaatan air hujan dan sangat bermanfaat dalam banyak kasus sumber daya air yang diperlukan. Pemanfaatan air hujan diperlukan di daerah yang memiliki curah hujan yang signifikan, namun sistem pasokan air secara konvensional dan terpusat tidak berfungsi dengan baik, dan juga di daerah di mana kualitas air permukaan atau air tanah yang kurang baik. Curah hujan tahunan berkisar antara kurang dari $500 \mathrm{~mm}$ sampai lebih dari $1500 \mathrm{~mm}$ dapat ditemukan di sebagian besar negara Amerika Latin dan Karibia. Sangat sering sebagian besar hujan turun selama beberapa bulan per tahun, dengan curah hujan sedikit atau tidak ada selama bulan-bulan yang tersisa. Ada negaranegara di mana distribusi tahunan dan regional curah hujan juga berbeda secara signifikan.

Selama lebih dari tiga abad, tangkapan dan penyimpanan tadah atap telah menjadi dasar penyediaan air rumah tangga di pulau-pulau kecil di Karibia. Selama Perang Dunia II, beberapa lapangan udara juga berubah menjadi tangkapan air hujan. Meskipun penggunaan sistem penangkapan air hujan dengan atap telah menurun di beberapa negara, namun diperkirakan masih lebih dari 500.000 orang di kepulauan Karibia bergantung setidaknya sebagian pada pasokan air hujan tersebut. Selanjutnya, area besar dari beberapa negara di Amerika Tengah dan Selatan, seperti Honduras, Brasil, dan Paraguay, penggunaan air dari hasil pemanenan air hujan merupakan sumber penting pasokan air untuk keperluan rumah tangga, terutama di daerah pedesaan.

\subsubsection{Deskripsi Teknis}

Sebuah sistem pemanfaatan air hujan terdiri dari tiga elemen dasar, yaitu area koleksi, sistem alat angkut, dan fasilitas penyimpanan. Tempat penampungan dalam banyak kasus adalah atap rumah atau bangunan. Luas efektif atap dan bahan yang digunakan dalam membangun atap mempengaruhi efisiensi pengumpulan dan kualitas airnya. Sebuah sistem pengangkutan biasanya terdiri dari talang atau pipa sebagai sarana pengaliran air hujan yang jatuh di atas atap untuk terkumpul dan mengalir ke suatu tempat penyimpanan atau tangki air penyimpan. Baik drainpipes dan permukaan atap harus terbuat dari bahan kimia lembam seperti kayu, plastik, aluminium, atau fiberglass, untuk menghindari efek buruk pada kualitas air. Air akhirnya disimpan dalam tangki penyimpanan atau tadah, yang juga harus terbuat dari bahan inert, seperti beton bertulang, fiberglass, atau stainless steel yang merupakan bahan yang cocok. Tangki Penyimpanan dapat dibangun sebagai bagian dari bangunan, atau mungkin dibangun sebagai unit terpisah letaknya agak jauh dari gedung. Gambar 3 menunjukkan skema dari sistem tangkapan atap di Republik Dominika.

\subsubsection{Pemanfaatan air hujan di Singapura}

Di Singapura, Changi Airport menggunakan sistem pengumpulan dan memanfaatkan air hujan, yang menyumbang $28-33 \%$ dari total air yang digunakan, serta menghasilkan penghematan sekitar \$ 390.000 (Dollar Singapura) per tahun. Potensi untuk menggunakan atap sebagai daerah tangkapan sudah sangat tinggi. Sistem yang dikembangkan ini merupakan hasil penelitian yang intensif dan terencana sangat baik. Singapura membuat program komputer yang sederhana untuk dikembangkan dan diaplikasikan berkaitan dengan gambar nomogram daerah atap, ukuran tangki dan roofwater yang harus tersedia. Dengan demikian setiap ada pengembangan bangunan, maka dengan cepat dapat ditentukan berapa volume air hujan yang dapat ditangkap dan dialirkan dalam tangkitangki air penyimpan air hujannya. Gambar 4 memberikan ilustrasi sistem penangkapan air hujan di bandara Changi di Singapura.

\subsubsection{Pemanfaatan air hujan di Tokyo, Jepang}

Di Tokyo sebuah arena Sumo-gulat di kota Sumida menggunakan air hujan dalam skala besar. Atap $8.400 \mathrm{~m}^{2}$ di arena ini berfungsi sebagai daerah 
tangkapan permukaan untuk sistem pemanfaatan air hujan. Sistem saluran mengumpulkan air hujan ke tangki penyimpanan sebesar $1.000 \mathrm{~m}^{3}$ di bawah tanah dan air hujan yang sudah tertampung tersebut digunakannya untuk menyiram toilet dan pendingin udara. Melalui contoh ini, banyak fasilitas umum baru termasuk Balai Kota yang sudah mulai memperkenalkan sistem pemanfaatan air hujan.

Pada tingkat masyarakat, fasilitas pemanfaatan air hujan sederhana dan unik, "Rojison", telah didirikan oleh penduduk setempat di distrik Mukojima Tokyo untuk memanfaatkan air hujan yang dikumpulkan dari atap rumah-rumah pribadi untuk penyiraman kebun, pemadam kebakaran dan air minum dalam keadaan darurat.

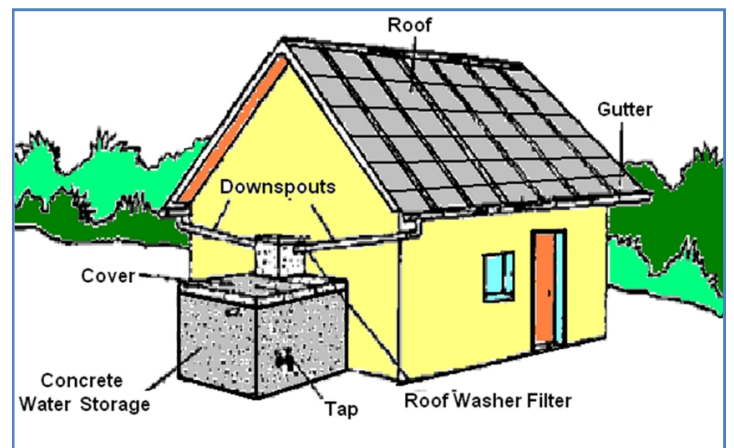

Gambar 3 : Skematik Sistem Pemanfaatan Air Hujan Dari Atap.

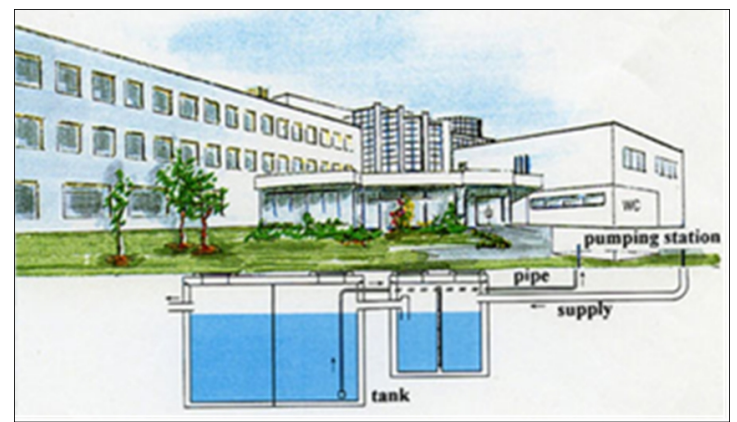

Gambar 4 : Skema Sistem Pemanfaatan Air Hujan Di Bandara Changi Singapura.

\subsubsection{Penampungan Air Hujan di Propinsi Gansu, China}

Provinsi Gansu terletak di dataran tinggi Loess di China tengah. Di wilayah ini curah hujan tahunan sangat variabel dengan $60 \%$ dari curah hujan tahunan terjadi di 3 bulan antara bulan Juli dan September. Rata-rata curah hujan tahunan adalah sekitar 300 milimeter. Secara tradisional, masyarakat Provinsi Gansu selalu tergantung pada air hujan sebagai sumber utama pasokan air. Dibuat penggalian 20 meter kubik tanah liat dan dikonstruksi berjajar tangki air bawah tanah di tanah untuk menyimpan aliran permukaan. Metode tersebut sudah sangat umum di daerah ini. Usaha ini tidak bisa selalu membantu ketersediaan air yang cukup dan orang-orang terpaksa untuk berjalan jauh ke sungai untuk mengambil air atau bergantung pada truk tangki air dari pemerintah.

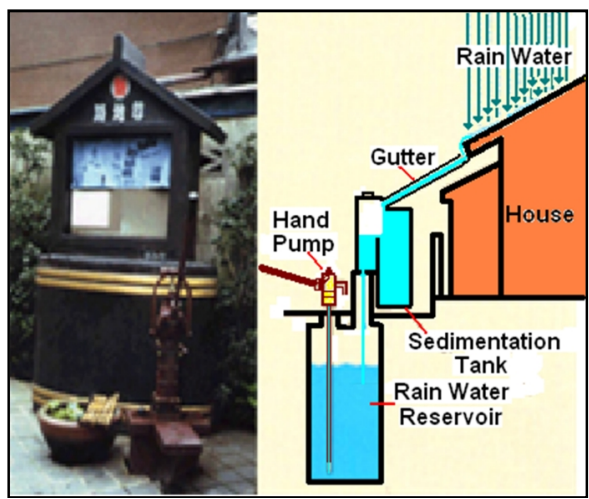

Gambar 5 : "Rojison", Fasilitas Pemanfaatan Air Hujan Yang Sederhana Dan Unik Di Tingkat Masyarakat Desa Di Jepang.

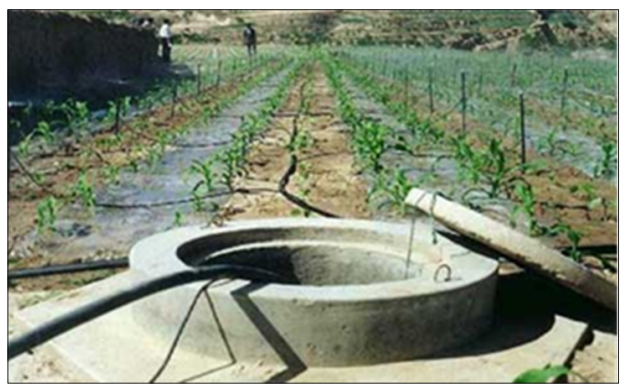

Gambar 6 : Skema Sistem Pemanfaatan Air Hujan Di Gansu, China.

The Gansu Research Institute meluncurkan proyek 1-2-1 untuk pemeliharaan air dengan dukungan dari pemerintah sementara. Proyekproyek ini didasarkan pada uji coba tes, pada demo plant dan proyek pilot yang dilaksanakan sejak tahun 1988. Setiap keluarga diberikan dengan satu unit atap (yang terbuat dari tanah liat) sebagai area tangkapan, dua tangki air dan terpal plastik untuk pengumpulan limpasan air hujan pada satu area. Tangki tanah liat tradisional Shuijiao diperbaiki dengan melapisinya dengan semen atau lempeng logam yang melekat pada dinding tanah tersebut. Tangki yang dipasang di atap dan halaman disemen untuk menggantikan daerah tangkapan tanah polos. Sebuah parit kemudian dibuat disekitarnya yang 
berfungsi sebagai sarana pengaliran untuk mengumpulkan air hujan dan air hujan yang tertampung dapat digunakan untuk menyiram sayuran di lahan pertanian mereka. Cara Ini sederhana, efektif dan murah, sehingga pendekatan proyek ini telah membantu lebih dari 200.000 keluarga dan memastikan bahwa sekitar satu juta orang memperoleh, bukan saja jumlah air yang cukup, tetapi juga hasil tanaman yang baik.

\subsubsection{Jar-sistem pemanfaatan air hujan di Thailand}

Thailand terletak di sabuk tropis dunia. Memiliki curah hujan melimpah, musim hujan berawall dari Mei hingga Oktober, ketika negara ini mengalami monsun barat daya. Curah hujan tahunan berkisar dari $102 \mathrm{~cm}$ di timur laut hingga lebih dari $380 \mathrm{~cm}$ di semenanjung.

Secara tradisional orang mengumpulkan air hujan untuk menggunakannya secara eksklusif untuk minum dan memasak. Orang disana lebih suka air hujan dari pada air lainnya semata-mata karena rasanya. Untuk rakyat pedesaan di Thailand umumnya menggunakan setidaknya dua sumber air. Air hujan yang ditampung dalam tangki guci, serta air tanah dangkal dari tabung sumur. Pembangunan lebih dari 10 juta guci forrocement dengan kapasitas beragam untuk penyimpanan air hujan di Thailand telah menunjukkan potensi dan kesesuaian sistem tangkapan sebagai teknologi pasokan air utama pedesaan.

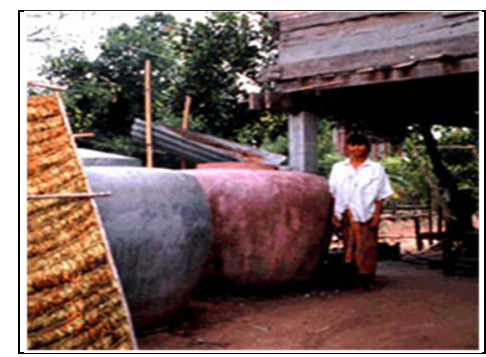

Gambar 7 : Stoples Atau Guci Penyimpan Air Hujan.

Pemanfaatan air hujan dengan guci hampir digunakan oleh semua rumah individu dan dengan demikian mereka memiliki akses di sepanjang tahun untuk air bersih. Wadah didatangkan dalam berbagai kapasitas dari 100 sampai 3.000 liter dan dilengkapi dengan tutup, keran, dan tirisan. Ukuran yang paling populer adalah 2.000 liter, dengan biaya 750 Baht, dan menyimpan air hujan cukup untuk sebuah rumah tangga (dengan anggota enam orang) selama musim kering yang berlangsung hingga enam bulan.

\subsubsection{Penerapan sistem pemanfaatan air hujan di Indonesia}

Indonesia adalah daerah tropis yang cukup tinggi curah hujannya, bahkan di dunia Indonesia termasuk dalam 5 negara yang terbanyak potensi air tawarnya. Namun demikian potensi air hujan yang besar sering menjadi masalah dibanyak tempat. Luapan air dari sungai sering menimbulkan banjir. Hujan yang lebat dan lama sering menimbulkan tanah longsor dan genangan air akibat saluran drainase tidak mampu menampung air hujan.

Seorang tenaga ahli dari Jepang, Makoto Murase, bersama Kelompok Raindrops, dalam Air Hujan dan Kita, Panduan Praktis Pemanfaatan Air Hujan (2008), menyampaikan 100 cara untuk memanfaatkan air hujan, yang biasanya dilakukan oleh masyarakat Jepang (117) dan masyarakat dunia (7). Negara yang pernah dikunjungi antara lain Bostwana, Kenya, Hawaii, Indonesia dan Tanzania. Pada tanggal 1-6 Agustus 1994, Tokyo Internasional Rainwater Utilization Conference mengadakan Konferensi dengan tema "Rainwater Utilization Saves the Earth - Form a Friendship with Raindrops in Cities ". Konferensi ini mencari jalan untuk untuk menyelaraskan hujan dengan rencana pembangunan kota. Sebagai hasilnya, lima poin berikut ditetapkan:

a. Penduduk di Asia, Amerika Latin dan Afrika akan terus memadati kota besar dan sebagai hasilnya, kota akan menghadapi masalah "Kekeringan Kota dan Banjir Kota" seperti yang dihadapi Tokyo, Jakarta dan lainnya.

b. Pelajaran bahwa Tokyo telah belajar sepenuhnya menolak hujan dan membuang air hujan ke got, dan kearifan baru Tokyo dalam teknik pemanfaatan air hujan tidak diragukan akan mengatasi "Kekeringan Kota dan Banjir Kota".

c. Pemanfaatan air hujan adalah tanggung jawab internasional bersama yang mempertimbangkan "pembangunan berkelanjutan" kota-kota.

d. Pemanfaatan air hujan secara langsung dihubungkan dengan polusi udara dan hujan asam.

e. Menciptakan budaya air hujan baru di mana kota dapat hidup dengan lebih harmonis dimana hujan diperlukan.

Untuk membangun suatu sumur resapan agar dapat memberikan kontribusi yang optimum diperlukan metoda perhitungan sebagai berikut (Sunjoto, 1992): 
a. Menghitung debit masuk sebagai fungsi karakteristik luas atap bangunan dengan formula rasional $(\mathrm{Q}=\mathrm{ClA}, \mathrm{Q}=$ debit masuk, $\mathrm{C}=$ Koefisien Aliran (jenis atap), I=Intensitas Hujan, A=Luas atap).

b. Menghitung kedalaman sumur optimum, yang diformulakan sebagai berikut (Formula Sunjoto 1988):

$$
H=\frac{Q}{F K}\left[1-e^{-\left(\frac{F K T}{\pi R^{2}}\right)}\right]
$$

$$
\begin{aligned}
& \text { Keterangan: } \\
& H=\text { Kedalaman air }(\mathrm{m}) \\
& \mathrm{Q}=\text { Debit masuk }(\mathrm{m} 3 / \mathrm{dt}) \\
& \mathrm{F}=\text { Faktor Geometric }(\mathrm{m}) \\
& \mathrm{K}=\text { Permeabilitas tanah }(\mathrm{m} / \mathrm{dt}) \\
& \mathrm{R}=\text { Radius sumur }(\mathrm{m}) \\
& \mathrm{T}=\text { Durasi aliran }(\mathrm{dt})
\end{aligned}
$$

c. Evaluasi jenis fungsi dan pola letak sumur pada jarak saling pengaruh guna menentukan kedalaman terkoreksi dengan menggunakan "multi well system".

Jika akan membangun sebuah sumur resapan dengan profil sumur seperti yang disajikan pada Tabel 1, maka perhitungan kedalaman sumur efektif dapat dihitung dengan menggunakan formula Sunjoto, dimana Faktor Geometri (F) tersebut disesuaikan dengan bentuk-bentuk potongan membujur sumur resapan yang akan dibangun.

Berdasarkan pengalaman berbagai negara yang telah menerapkan sumur resapan dan telah menunjukkan keberhasilan program tersebut, maka Pemerintah Indonesia telah mengeluarkan berbagai peraturan dan perundang-undangan yang mengharuskan aplikasi sumur resapan untuk memanfaatkan air hujan dan sekaligus mengkonservasi air tanahnya. Bahkan dalam aplikasi di berbagai daerah telah dilakukan paduan antara penampungan air hujan, sumur resapan dan pengolahan air hujan untuk memenuhi kebutuhan air minum bagi suatu komunitas secara terbatas. Pusat Teknologi Lingkungan, BPPT telah mengaplikasikan program paduan tersebut di Pandeglang, tepatnya di Pesantren Daar El Fallah. Sistem penampungan air hujan yang diterapkan dapat dilihat pada Gambar 8.

Dengan kapasitas bak PAH yang cukup besar, maka manfaatnya sangat berarti, yaitu pada saat musim kemarau, air hujan tersebut dapat digunakan sebagai air baku untuk kebutuhan air minum, minimal bagi para siswa di dalam lingkungan pesantren.

Tabel 1 : Tabel Geometrik Sumur Resapan.

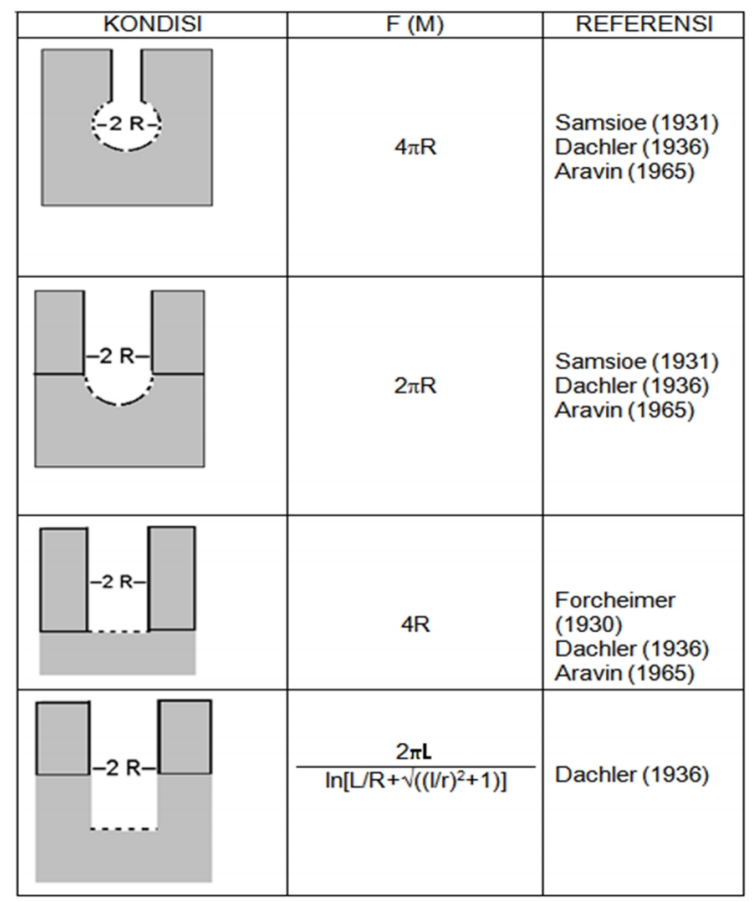

\section{KESIMPULAN DAN SARAN}

\subsection{Kesimpulan}

1. Air hujan sebenarnya adalah suatu anugerah alam yang berlimpah dan merupakan sumber air yang selayaknya dimanfaatkan secara arif oleh manusia, terutama pada musim penghujan.

2. Pengelolaan dan pemanfaatan air hujan yang baik (dengan sumur resapan) akan membawa manfaat yang sangat besar, yaitu sebagai sumber air bersih atau air minum, mencegah bencana banjir, tanah longsor, mencegah penurunan muka tanah dan sekaligus melakukan konservasi air tanah.

3. Pemanfaatan air hujan sebagai sumber air untuk pemenuhan kebutuhan air minum maupun air bersih sudah dilakukan sejak dulu di berbagai belahan dunia, seperti di Republik Dominika, Singapura, Jepang, China, Thailand dan Indonesia.

4. Aplikasi pemanfaatan air hujan di suatu komunitas masyarakat tertentu merupakan bukti sarana edukasi positif baik bagi masyarakat itu sendiri maupun pemerintah daerah setempat. 


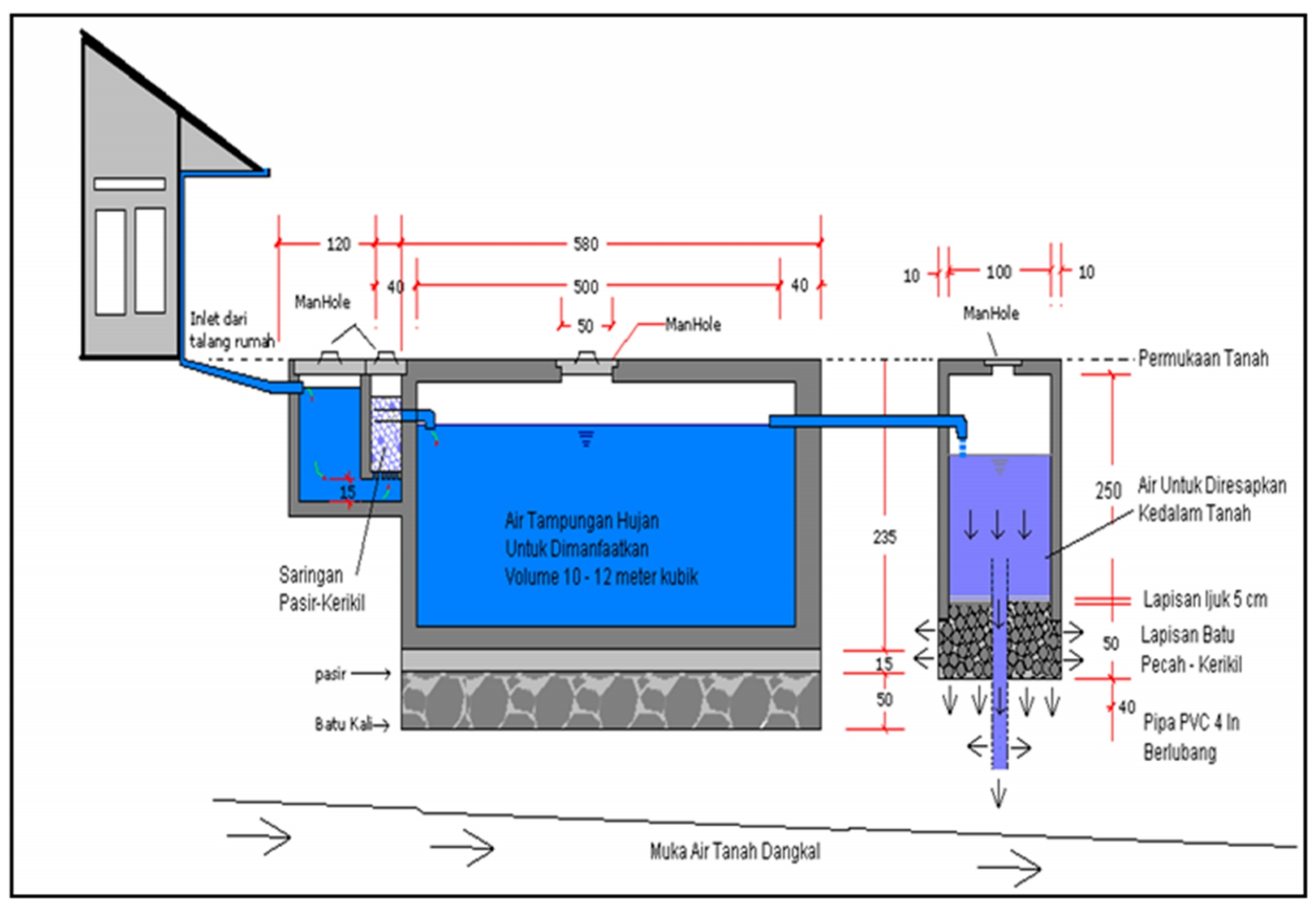

Gambar 8 : Gambar Disain Sumur PAH Dan Sumur Resapan Di Pesantren Di Daar El Fallah, Pandeglang.

Tabel 2 : Volume Sumur Resapan Pada Kondisi Tanah Permeabilitas Rendah (SK. Gub DKI Jakarta No. 20 Th. 2013).

\begin{tabular}{|c|c|c|c|}
\hline NO & $\begin{array}{c}\text { LUAS } \\
\text { KAVLING } \\
\left(\mathrm{M}^{2}\right)\end{array}$ & $\begin{array}{c}\text { VOLUME RESAPAN ADA } \\
\text { SALURAN DRAINASE } \\
\text { SEBAGAI PELIMPAHAN } \\
=\text { V1 } \\
\left(\mathrm{M}^{3}\right)\end{array}$ & $\begin{array}{c}\text { VOLUME SUMUR RESAPAN } \\
\text { TANPA ADA SALURAN } \\
\text { DRAINASE SEBAGAI } \\
\text { PELIMPAHAN =V2 } \\
\left(\mathrm{M}^{3}\right)\end{array}$ \\
\hline 1. & 50 & $1,3-2,1$ & $2,1-4$ \\
2. & 100 & $2,6-4,1$ & $4,1-7,9$ \\
3. & 150 & $3,9-6,2$ & $6,2-11,9$ \\
4. & 200 & $5,2-8,2$ & $8,2-15,8$ \\
5. & 300 & $7,8-12,3$ & $12,3-23,4$ \\
6. & 400 & $10,4-16,4$ & $16,4-31,6$ \\
7. & 500 & $13-20,5$ & $20,5-39,6$ \\
8. & 600 & $15,6-24,6$ & $24,6-47,4$ \\
9. & 700 & $18,2-28,7$ & $28,7-55,3$ \\
10. & 800 & $20,8-32,8$ & $32,8-63,2$ \\
11. & 900 & $23,4-36,8$ & $36,8-71,1$ \\
12. & 1.000 & $26-41$ & $41-79$ \\
\hline
\end{tabular}

\subsection{Saran}

1. Perlu diadakan sosialisasi tentang pemanfaatan air hujan secara lebih luas dan intensif yang melibatkan sebanyak mungkin unsur pemerintah, swasta dan masyarakat.

2. Selayaknya dikaji betul untuk menerapkan peraturan yang lebih mengikat, misalnya di setiap pesantren, perkantoran ataupun perumahan yang membutuhkan air minum serta gedung perkantoran dan gedung-gedung yang mengokupasi lahan dan dengan tutupan lahan yang menghalangi meresapnya air ke dalam tanah diwajibkan membuat sumur resapan yang dilengkapi dengan pemanenan air hujan.

3. Program konservasi air tanah pada khususnya dan konservasi sumberdaya air pada umumnya perlu dijadikan bagian dari kurikulum di sekolah dari tingkat dasar hingga menengah atas, agar setiap murid dapat memahami perlunya mengelola sumberdaya air sesuai dengan tingkatan kemampuannya. Dengan demikian pada gilirannya, pengetahuan ini akan dibawa ke lingkungan sekitar tempat tinggalnya dan diharapkan dapat berbuat sesuatu untuk mengkonservasi sumberdaya air.

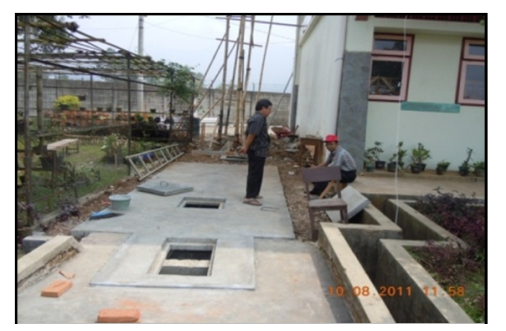

Gambar 9 : Pembangunan/Konstruksi PAH Dan Sumur Resapan Di Pesantren Daar El Fallah, Pandeglang. 


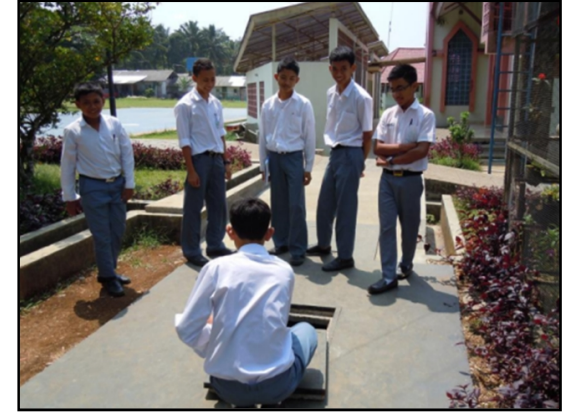

Gambar 10 : Sosialisasi PAH Dan Sumur Resapan Kepada Para Siswa Di Pesantren Daar El Fallah.

\section{DAFTAR PUSTAKA}

- Anonim - 16. 1983. Masterplan for Jakarta water supply development project. Interim Report. Desember 1983. JICA. Jakarta

- Anonim - 17. 1997. Injection. Water Factory 21. http://www.ocwd.com/wf 21_09.htm. Orange County Water District.

- Anonim - 18. Wilayah. 2000. Studi Banjir di Wilayah Kamal - Cengkareng - Kapuk. Propinsi DKI Jakarta. Puslitbang Teknologi Sumber Daya Air Departemen Pemukiman dan Prasarana. Jakarta.

- Anonim - 2. 1974. Undang-Undang Republik Indonesia Nomor 11 Tahun 1974 Tentang Pengairan.

- Anonim - 4. 2004. Undang Undang Republik Indonesia Nomor 7 tahun 2004 tentang Sumberdaya Air. http://sda.kimpraswil.go.id/info/uu.asp

- Anonim - 5. 1996. Peta Geologi Tata Lingkungan Indonesia. Lembar: DKI Jakarta. Direktorat Geologi Tata Lingkungan. Bandung.

- Chow, Van Te. 1960. Handbook of Applied Hydrology. McGraw-Hill Book Co., Inc. N.Y.

- Cordery,I. 1976, Evaluation And Improvement of Quality Characteristics of Urban Stormwater. New South Wales, Australia, The University of New South Wales School Of Civil Engineering.

- Deny, J. 1994. Kelestarian Imbuhan Air Tanah Dengan Memanfaatkan Teknologi Konservasi
Air Tanah. Dalam Seminar Memasyarakatkan Penggunaan Air tanah di Wilayah Jakarta Seefisien Mungkin. Jakarta, 26 Oktober 1994.

- Dinas Pertambangan Daerah Tingkat I Jawa Tengah dengan Direktorat Geologi Tata Lingkungan. 1995. Pengamatan Resapan Air bawah Tanah daerah Semarang dan Sekitarnya. Semarang. Proyek Pengawasan dan Pengendalian Pengambilan Air Bawah Tanah di Kodya Semarang, Surakarta Kabupaten semarang, Kendal dan Sukohardjo.

- Kalsim, D.K. 2007. Catatan Kuliah Hidrologi Teknik Lanjutan. Jurusan Sipil dan Lingkungan. IPB.Bogor.

- Kirpich, P.Z.1940. Time of Concentration of Small Agricultural watershed. Civil Eng.:10:362.

- Kurniatun Hairiah et al.,2004. Ketebalan seresah sebagai indikator Daerah Aliran Sungai (DAS) sehat. World Agroforestry Centre, Bogor.

- Pemerintah Daerah Khusus Ibukota Jakarta, Brosur, Sumur Resapan Buatan Air Hujan. Jakarta, Dinas Pertambangan DKI, 2010.

- Samsuhadi. 2009. Pemanfaatan Air Tanah jakarta. Jurnal Air Indonesia. Vol 5. No 1. Juni 2009. Pusat Teknologi Lingkungan. Deputi TPSA. BPPT. Jakarta

- Sudinda, Teddy. Dkk. 2009. Kajian dan Penerapan Teknologi Artificial Recharge Air Tanah Dalam untuk Mengatasi Banjir dan Kekeringan. Prosiding Workshop Teknologi Imbuhan Buatan untuk Mengatasi Banjir dan Kekeringan. Deputi Bidang Pendayagunaan dan Pemasyarakatan IPTEK. Kementrian Negara Riset dan Teknologi. Jakarta. Oktober 2009.

- Sunjoto. 1992. Brosur Sistem Drainase Air Hujan Berwawasan Lingkungan. Yogyakarta. Fakultas Teknik Universitas Gadjah Mada.

- SK Gubernur DKI Jakarta Raya No. 20 Tahun 2013 tentang Sumur Resapan.

- Wisler, C.O., and E.F. Brater. 1959. Hydrology. John Wiley \& Sons, Inc., New York. 